\section{South Africa: telescopes raise the nation's sights}

In your Editorial and News Feature on South African science (Nature 463,709 \& 726-728; 2010), you are critical of the country's bid to host the Square Kilometre Array (SKA) radio telescope. But from an astronomer's viewpoint, there is every reason to be optimistic.

In the 2002 National Research and Development Strategy, astronomy was identified as the first of four areas in which South Africa has an obvious geographic advantage (the others being human palaeontology, biodiversity and Antarctic research).

The result was the construction of the Southern African Large Telescope (SALT) at the South African Astronomical Observatory (SAAO). South Africa contributed one third of the US\$20-million cost, with the remainder being made up by international partners.

Two-thirds of the construction costs were spent within the country, providing a muchneeded stimulus to South African industry, technology transfer and student training. The SKA would do this and a great deal more.

SALT has been more than a tool for the research community. Its success has extended beyond South Africa, aided by grants from the International Astronomical Union (IAU) for 2009 - the International Year of Astronomy. The SAAO is a role model in the IAU's plans for astronomy in the developing world. The observatory hopes to host the IAU's Office for Astronomy Development, which aims to use astronomy as "a unique and cost-effective tool for furthering sustainable global development".

The implication that Phil Charles, director of the SAAO, has ever done anything but wholeheartedly support South Africa's SKA bid is without foundation. In fact, the first African Physical Society resolution on supporting the SKA bid in Africa, written by
Phil Charles with US astronomer Charles McGruder, was passed "by acclamation" at the society's Dakar meeting last month. They, like me, wish to see the prototype telescope MeerKAT and potential SKA operations centre benefiting from the existing SAAO facility, so that radio and optical astronomers can collaborate.

As the South African government proclaimed in 1996, scientific endeavour is not purely utilitarian in its objectives: it has important associated cultural and social values. Not to develop flagship sciences such as physics and astronomy would brand us as a second-class nation.

Patricia Whitelock South African Astronomical Observatory, PO Box 9, Observatory 7935, South Africa e-mail:paw@saao.ac.za

\section{South Africa: aiming to be premier global astronomy hub}

As director-general of science and technology in South Africa during the period when the major programmes reviewed in your News Feature were initiated (Nature 463, 726-728; 2010), I strongly believe that we should still be championing big science projects such as the Square Kilometre Array (SKA) radio telescope.

When the African National Congress government began reshaping South African science after apartheid, we asked ourselves what resources we had that might attract good scientists from abroad. One is the night sky: astronomers from the Northern Hemisphere need access to observations from the Southern Hemisphere (unless they study neutrinos, which go straight through the Earth). Southern Africa has excellent viewing sites, in all three wavelength bands detectable from Earth.

This sparked an ambitious programme that resulted in the construction of the High Energy Stereoscopic System telescope in Namibia ( $\gamma$-rays) and the Southern African Large Telescope (visible light), and we have now made our pitch for the SKA (radio waves). The aim is to become the premier global astronomy hub.

If the SKA and the MeerKAT telescope project were to be eliminated, then the money being poured into them would not be diverted to other scientific ventures - funding doesn't work like that. The Department of Science and Technology's budget would simply decrease by $14 \%$.

You take former president Thabo Mbeki to task for apparently having failed to achieve his own vision of an African science, but Mbeki had a different vision: that Africa should become world class.

Rob Adam PO Box 189, Groenkloof 0027, South Africa

e-mail: rob.adam@necsa.co.za

\section{South Africa: big science should stay on the agenda}

Your News Feature on South African science (Nature 463, 726-728; 2010) suggests that without financial support from abroad, research endeavours would all but collapse. But there are positive developments.

For example, instead of the poorly funded young researcher you describe, you could have selected at least three others from the same field, cohort, gender and institution who are comparatively well funded by the National Research Foundation (NRF).

It is also worth pointing out that the Department of Science and Technology, through the NRF, is supporting seven centres of excellence, amounting to a total of hundreds of millions of rands over their lifetimes. Five of these (three directly and two indirectly) are concerned with biodiversity research - identified as one of the country's major strengths.

Most of my research is funded by national sources and, acknowledging the confounding impact of career progression, has grown exponentially since 1994. More research opportunities have been created as spending on research and development increased by nearly $50 \%$ over this period to 2007. The global financial crisis notwithstanding, 'big science' aspirations should stay on South Africa's agenda. Steven L. Chown Centre of Excellence for Invasion Biology, Stellenbosch University, Private Bag X1, Matieland 7602 , South Africa e-mail: slchown@sun.ac.za

\section{Myth-busting about first mass-produced human cell line}

In Steve Silberman's Book Review of The Immortal Life of Henrietta Lacks (Nature 463, 610; 2010), two myths about HeLa cells are perpetuated.

Your lead-in claims that the death of Henrietta Lacks "led to the first immortal cell line", but that distinction belongs to the L929 cell line, which was derived from mouse connective tissue and described almost a decade earlier (W. Earle J. Natl Cancer Inst. 4, 165-212; 1943). As Silberman notes, Lacks's was the first mass-produced human cell line. And HeLa's alleged growth "with mythological intensity... doubling their numbers every twenty-four hours...", quoted from the book itself, is no different from the doubling time of cultured normal human cells (L. H. and P. S. Moorhead Exp. Cell Res. 25, 585-621; 1961).

The numbers of HeLa cells produced during the first few years of the line's existence in vitro were unremarkable because of the explant technique used at the time. Production of large numbers became possible several years later, with the introduction of the monolayer culture technique that is still in common use.

\section{Leonard Hayflick University of} California, San Francisco, PO Box 89, The Sea Ranch, California 95497, USA e-mail: lenh38@aol.com 